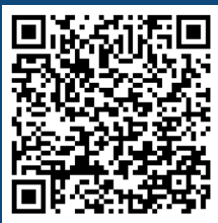

Keywords:

Biofertilizer

Copaiba

Forestry nursery

Nutrition

Morphophysiological

Received 20/I I/2019

Accepted |4/03/2020

Correspondence: cacioboechat@gmail.com
Cácio Luiz Boechat ${ }^{\mathrm{la}+}$, Ayrton Senna da Silva Damasceno ${ }^{\mathrm{lb}}$, Cíntia Bezerra Rocha ${ }^{\mathrm{lc}}$, Adriana Miranda de Santana Arauco'd , Helane França Silvale

\section{ORGANIC RESIDUES IN THE COMPOSITION OF SUBSTRATES ENRICHED WITH BOKASHI BIOFERTILIZER FOR THE SUSTAINABLE PRODUCTION OF Copaifera langsdorffii SEEDLINGS}

BOECHAT, C. L.; DAMASCENO, A. S. S.; ROCHA, C. B.; ARAUCO, A. M. S.; SILVA, H. F. Organic residues in the composition of substrates enriched with bokashi biofertilizer for the sustainable production of Copaifera langsdorffii seedlings. CERNE, v. 26, n. I, p. I8-25, 2020.

\section{HIGHLIGHTS}

Highest morphophysiological quality was observed with goat manure or carnauba residue.

Bokashi improves the morphophysiological variables of seedlings, except chlorophyll.

Goat manure with or without bokashi provides higher macronutrient content in the shoot.

Phosphorus is made available according to the need of the plants with bokashi.

\section{ABSTRACT}

One of the great challenges in the post-nursery phase is to plant seedlings in the field. It is, therefore, important to produce them to a high standard of quality aiming to achieve an economically feasible and environmentally sustainable process. For this purpose, the use of organic residues in the composition of substrates, associated with biotechnologies available on the market, is a feasible alternative, which, however, requires further research for process optimization. Thus, the objective was to evaluate the morphophysiological characteristics, nutrition and quality of Copaifera langsdorffii seedlings in substrates formulated with organic residues and Fertbokashi premium ${ }^{\circledR}$. The treatments were distributed in a randomized block design, with four repetitions, in a $5 \times 2$ factorial scheme, with four substrates (carnauba residue, goat manure, unprocessed and carbonized rice husks) and one control (soil) with or without applying bokashi. A part of the results, the highest values observed in the morphophysiological and nutritional variables, were for plants grown in the substrate with carnauba residue, followed by goat manure, both in association with bokashi. Among the residues studied, carnauba residue had the highest $\mathrm{N}$ and $\mathrm{P}$ contents and the lowest $\mathrm{C}: \mathrm{N}$ ratio, raising the quality variables. The use of bokashi associated with the residues promotes the best results for most of the morphophysiological and nutritional parameters of the Copaiba seedlings. The substrates formulated with carnauba residue and goat manure are the most appropriate for seedling production. The regional residues can be used as a substrate to produce Copaiba seedlings to a high standard of quality.
' Federal University of Piauí, Bom Jesus, Piauí, Brazil- ORCID: 0000-0002-5086-9156a, 0000-0002-3337-7|25b, 0000-0002-5873-3536c, 0000-0002-2538-777Xd , 0000-0002-1762-0965 


\section{INTRODUCTION}

Brazil is one of the main producers and consumers of wood products in forestry worldwide (IBÁ, 20I7). Thus, it is of the utmost importance to produce seedlings to a high standard of quality and aiming at a productive, economically feasible and environmentally sustainable production process. In this sense, the use of organic residues in substrate composition is a feasible alternative to produce forest tree species seedlings (Moreira et al., 2018; Mayer et al., 20l0; Nóbrega et al., 2008), but it requires research to optimize the quality seedling production process.

Studies of forest tree seedlings describe the positive effects of using organic residues such as: growth and quality of seedlings, including the increment in height and diameter, more dry mass and others (Amaral et al., 2016; Araújo et al., 2018; Jaramillo-López et al., 2015). Besides improving the fertility of soil and substrates, the residues applied raise the organic matter content and help increase the quality of the physical, chemical and biological attributes (Boechat et al., 20I2; Boechat et al., 2017; Jaramillo-López et al., 2015; Rocha, 2013).

However, the proportions of nutrients in most organic residues are out of balance in relation to those required by the plants, and thus require complementation with commercial fertilizers (Rocha, 20I3). The fermented compost, bokashi, may be a feasible alternative in the cycling of nutrients in substrates with organic residues, since it is a balanced mixture of organic matter of plant and/ or animal origin, submitted to a controlled fermentation process that, besides acting as a source of nutrients for the plant, also stimulates increased diversity and microorganism activity in the substrate (Boechat et al., 2013; Jaramillo-López et al., 2015; Shin et al., 2017).

Some residues can potentially be used in the composition of substrates containing characteristics that are desirable for the production of forest tree seedlings. However, so far there have been few studies evidencing the effect of the organic residues on the growth and nutrition of the Copaifera, which is a genus of trees that are native to the tropical regions of Latin America and West Africa (Danilevicz et al., 2018).

In Brazil the Copaifera langsdorffii Desf species is popularly known as Copaiba. It is abundant in the Cerrado, Atlantic Forest and Caatinga biomes, and the species is used mainly to produce oil extracted from the trunk, which has medicinal properties and antimicrobial and anti-inflammatory action (Oliveira et al., 2006). It also has the potential to restore degraded areas and for phytoremediation (Asensio et al., 2018). However, there is lack of information to improve the production of quality seedlings.

This study was conducted under the assumption that the addition of the bokashi compost to organic substrates improves the quality of the Copaiba seedlings during the nursery phase. Thus, the intention was to evaluate the morphophysiological characteristics, nutrition and quality of the Copaifera langsdorffii seedlings in substrates formulated with organic residues with and without the addition of fermented bokashi compost.

\section{MATERIAL AND METHODS}

The experiment was conducted in a greenhouse with $50 \%$ shade, located at the geographic coordinates

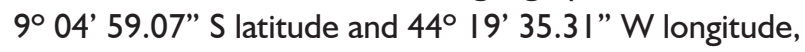
close to the municipality of Bom Jesus, state of Piauí. The climate of the region is classified as $\mathrm{Cwa}$, which corresponds to a temperate and humid climate, with a dry winter and hot summer (Köppen, 1948). The mean monthly values of temperature and relative air humidity during the experimental period are shown in Figure I.

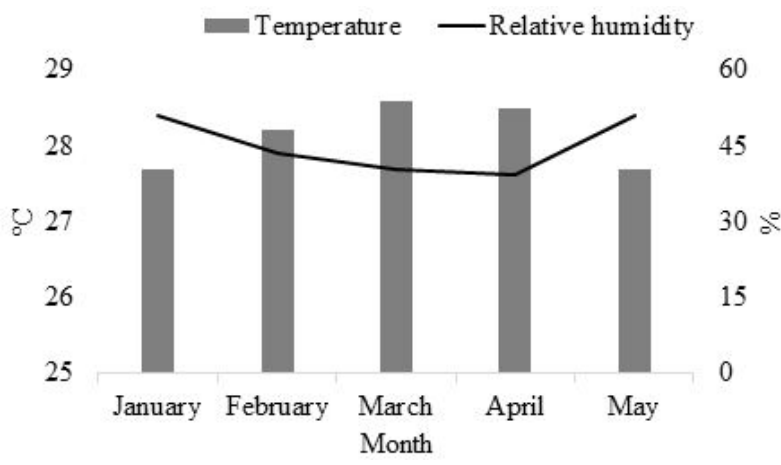

FIGURE I Mean monthly air temperature $\left({ }^{\circ} \mathrm{C}\right)$ and relative humidity (\%) based on climate conditions during the experimental period.

The treatments were distributed in a design with randomized blocks and four repetitions in a $5 \times 2$ factorial scheme. Four substrates were formed from the mixture of soil and organic residues (carnauba residue, goat manure, in natura rice husks and carbonized rice husk) at a proportion of $\mathrm{I}: \mathrm{I}(\mathrm{v} / \mathrm{v})$ and a control treatment with soil only, with or without applying the fermented bokashi compost.

Carnauba residue was obtained from the agroindustrial residue of the carnauba tree [Copernicia prunifera (Mill.) H.E. Moore]. The goat manure was composted for approximately 20 days. The organic residues were chemically characterized according to the methodology described by Teixeira (2017) (Table I).

The bokashi chemical compost (Bokashi premium $\left.{ }^{\circledR}\right)$ used presents the following chemical 
TABLE I Chemical characteristics of the organic residues used in the composition of the substrates for the production of Copaiba seedlings.

\begin{tabular}{|c|c|c|c|c|c|c|c|c|c|}
\hline \multirow{2}{*}{ Organic residue ${ }^{(l)}$} & $\mathrm{N}$ & $P$ & $\mathrm{~K}$ & $\mathrm{Ca}$ & $\mathrm{Mg}$ & $\mathrm{Zn}$ & $C$ & C:N ratio & C:P ratio \\
\hline & $\%$ & & $\mathrm{~kg}^{-1}$ & \multicolumn{3}{|c|}{$\mathrm{mg} \cdot \mathrm{kg}^{-1}$} & $\%$ & - & \\
\hline $\begin{array}{c}\text { Agroindustry } \\
\text { carnauba residue }\end{array}$ & 4.9 & 1.5 & 3.0 & 202.8 & 9.8 & 18.0 & 79.8 & 16.3 & 532.0 \\
\hline Goat manure & 3.0 & 7.6 & $<\mathrm{LD}$ & 204.6 & 21.5 & 4.5 & 70.1 & 23.5 & 92.2 \\
\hline $\begin{array}{c}\text { Rice husks in } \\
\text { natura }\end{array}$ & 0.4 & 0.6 & 1.5 & 28.6 & 6.4 & 4.45 & 15.2 & 259.7 & 1515.0 \\
\hline $\begin{array}{c}\text { Carbonized rice } \\
\text { husks }\end{array}$ & 0.8 & 0.4 & 1.0 & 27.7 & 4.9 & 14.8 & 62.2 & 78.7 & I555.0 \\
\hline
\end{tabular}

'Chemical characterization according to the methodology described by Empresa Brasileira de Pesquisa Agropecuária (Teixeira et al., 20I7). < LD below the detection limit

composition: total nitrogen $=1.5 \%$; total organic carbon $=15 \%$; density $=1,135 \mathrm{~g} \cdot \mathrm{L}^{-1} ; \mathrm{pH}=3.8$; electric conductivity $=13 \mathrm{mS} \cdot \mathrm{cm}^{-1}$; salt index $=10$. The product was activated according to the manufacturer's guidelines.

The soil used in the mixtures was collected in the $0-20 \mathrm{~cm}$ layer after removal of the organic layers on a surface composed by plant remnants and then dried in the shade. The clods were broken and the soil was put through a sieve with a $4 \mathrm{~mm}$ mesh. The soil was classified as or according to Soil Survey Staff (2014) as Oxisol. A sub-sample was used for the physical and chemical characterization of the soil, according to a methodology described in Tedesco et al. (1995) (Table 2).

TABLE 2 Chemical and physical characteristics of a soil sample used in the composition of substrate for the production of Copaiba seedlings.

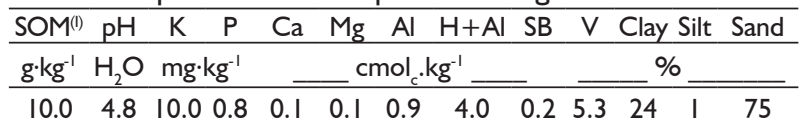

'SOM - soil organic matter; H+Al - potential acidity; SB - sum of bases; $\mathrm{V}$ saturation by bases.

The experimental units (EU) consisted of polyethylene tubettes with a $100 \mathrm{~mL}$ volume, filled with the substrates that originated from the mixture of soil and organic residue at a ratio of $\mathrm{I}: \mathrm{I}(\mathrm{v}: \mathrm{v})$ and moistened to close to $70 \%$ of the water retention capacity for each treatment during 15 days, in order to re-establish the microbial population. Next, three seeds of a single tree matrix were sown in each EU, having previously been submitted to breaking of dormancy by mechanical scarification, utilizing $\mathrm{n}^{\circ} 30$ sandpaper and disinfestation in a solution of hypochlorite potassium at $6 \%$ for five minutes in order to eliminate possible pathogens.

Twenty-five (25) days after complete germination, the seedlings were thinned out, leaving them visually more vigorous per EU. At 0,30 and 60 days after thinning out, the Fertbokashi premium ${ }^{\circledR}$ was applied at a dose of $0.5 \mathrm{~mL} \mathrm{EU}^{-1}$ around the collar directly on the substrate, according to the company recommendations for perennial species.
Irrigation was periodically performed during the experiment, maintaining moisture close to $70 \%$ of the retention capacity. Ninety days after thinning out, the seedlings were collected, separating the aerial part of the root. The roots were washed in running water to remove the material that stuck to them.

The length of the aerial part (LAP) was evaluated taking the terminal apical merystem, as well as the root length (RL), diameter of the root collar (RC) 0.05 measured with a precision pachymeter; number of leaves (NL); dry mass of the aerial part (DMAP) and dry root mass (DRM). The dry matter was quantified by weighing after drying in an oven at $65^{\circ} \mathrm{C}$, for a period of approximately 72 hours until constant mass was reached. The height/root collar diameter $(H / R C)$ ratio, dry mass of the aerial part/dry root mass (DMAP/DRM), Dickson Quality Index (DQI) and physiological variables: Chlorophyll a and Chlorophyll b, measured with a portable chlorophyll meter (ClorofilLOG), model Falker CFLI 030 were also calculated.

The concentrations of macronutrients $\mathrm{P}, \mathrm{K}$, $\mathrm{Ca}$ and $\mathrm{Mg}$ in the dry mass of the aerial part were determined after grinding in a Wiley type mill, weighing and digestion with a nitric-perchloric acid solution. The $\mathrm{P}$ contents were determined by colorimetry, those of $\mathrm{K}$ by flame photometry, $\mathrm{Ca}$ and $\mathrm{Mg}$ by atomic absorption spectrophotometry using certified plant material as standard sample (Teixeira et al., 20I7).

The data were submitted to analysis of variance (ANOVA), using the $\mathrm{F}$ test at the level of $5 \%$ significance and when the means were significant, submitted to Tukey's test $(p<0.05)$, using the Sisvar statistical program (Ferreira, 20I I).

\section{RESULTS AND DISCUSSION}

The higher value for length of aerial part (LAP) was observed in the treatment with carnauba residues (CR). Among the residues used in the composition of substrates, $\mathrm{CR}$ presents higher nitrogen and phosphorus contents and the lowest $\mathrm{C}: \mathrm{N}$ ratio, thus providing increments in the aerial part of seedlings (Tables I and 3). Guedes et al. (20II), observed that one of the most required nutrients for the development of Copaiba is nitrogen, and when it is left out there is a smaller increment of the aerial part and root. Amaral et al. (2016) and Araújo et al. (2016) also looked at the increased mass of the aerial part of seedlings produced in substrate containing carnauba residue corroborating the results found in this study.

For the variable diameter of root collar (RC), the lowest values were observed in treatments with carbonized rice husks $(\mathrm{CRH})$ and controls (2.47 and $2.34 \mathrm{~mm}$, respectively) (Table 3). The smaller mean obtained in the $\mathrm{CRH}$ treatment can be attributed to the 
TABLE 3 Length of aerial part (LAP), diameter of root collar (RC), number of leaves (NL) and number of folioles (FOL) of Copaiba seedlings produced with regional organic residues.

\begin{tabular}{|c|c|c|c|c|}
\hline \multirow{2}{*}{ Treatment ${ }^{(l)}$} & LAP & $\mathrm{RC}$ & $\overline{\mathrm{NL}}$ & FOL \\
\hline & $\mathrm{cm}$ & $\mathrm{mm}$ & \multicolumn{2}{|c|}{ unit- } \\
\hline $\mathrm{NRH}$ & $12.67 \mathrm{~b}$ & $2.53 a b$ & $2.25 c$ & $8.12 \mathrm{~b}$ \\
\hline GM & $14.45 b c$ & $2.74 a b$ & $2.50 \mathrm{bc}$ & $10.12 a b$ \\
\hline $\mathrm{CRH}$ & $15.18 b c$ & $2.47 \mathrm{~b}$ & $2.87 a b c$ & $10.62 \mathrm{ab}$ \\
\hline$C R$ & $20.56 a$ & $2.96 a$ & $3.37 a b$ & $12.87 \mathrm{a}$ \\
\hline Test & $16.82 \mathrm{~b}$ & $2.34 \mathrm{~b}$ & $3.75 \mathrm{a}$ & $12.00 \mathrm{ab}$ \\
\hline C.V. (\%) & 11.28 & 12.26 & 23.52 & 25.64 \\
\hline
\end{tabular}

'NRH - in natura rice husk; GM - goat manure; CRH - carbonized rice husks; CR - carnauba residue; Test - soil without residue, Means followed by the same letter are not different from each other according to Tukey's test at $5 \%$; C.V.\% = coefficient of variation.

low nutritional quality of this residue, which presented the lowest macronutrient contents, together with the in natura rice husk (NRH) when compared to the other residues (Table I).

Paiva et al. (2010), observed a similar effect in seedlings of arboreal species in the Cerrado, which are less developed when cultivated in substrate formed by soil and carbonized rice husk. In these cases, an alternative is to use commercial fertilizers during the growth of the seedlings, however, the process is more expensive.

The number of leaves (NL) and folioles (FOL) was also affected by the type of treatment, and the highest values were observed in the treatment with carnauba residue and control, while the lowest values were found in seedlings produced with in natura rice husk (Table 3). Reis et al. (2013) mention that these variables are related to the production of photoassimilates and that the greater the number of leaves the higher will be the photosynthetic conversion and consequently the greater the seedling growth.

Carnauba residue is a plant residue that presents the physical and chemical characteristics appropriate for the composition of substrates (Araújo et al., 2016). However, Jeromini et al. (2017), studying the growth of Copaiba seedlings in substrates formulated with organic compounds, found an effect similar to that presented in this study, whose substrate, formed with soil, obtained an increment in the number of leaves equivalent to soil with a commercial substrate. Also, according to the authors, the results suggest that it is not possible to generalize the beneficial effect of adding organic residues in seedling production and that the results may be contradictory when one works with a given species, since several factors may be involved in obtaining seedlings, such as the required standard of quality.

For the variable dry mass of the aerial part (DMAP), the highest value $(0.75 \mathrm{~g}$, respectively) was observed using carnauba residue as a substrate (Table 4). Studying doses of organic compost and carnauba residue in the production of Leucaena leucocephala (Lam.) de
Wit, Amaral et al. seedlings (2016) they observed similar results for the height of plants produced in substrate with approximately $62 \%$ of this organic residue in its composition. Also, Damasceno et al. (2019) observed increases in the height and quality of seedlings in which carnauba residue was used. The best results observed for plants cultivated in a substrate with carnauba residue in its composition reflect the greater wealth of nutrients present in this residue (Table I).

Higher values for morphological variables such as length, dry mass of the aerial part, root collar diameter, number of leaves and folioles are very desirable to produce seedlings, since these are key parameters to estimate survival, initial growth and performance of the seedlings after planting in the field (Amaral et al., 2016; Gomes et al., 2003). Besides, seedlings with higher values of height, root length and diameter make planting easier, mainly reducing losses due to physical damage in transport and in handling in the field (Tsukamoto Filho et al., 2013).

The LAP/RC ratio indicates the equilibrium of the seedling development and its capacity to survive in the field (Carneiro, 1995). Thus, it is shown that the treatments with the addition of carnaúba residue $(7,17)$, carbonized rice husks $(6,17)$ and the control $(7,10)$, showed greater stability of plant growth and are more likely to present a better performance under adverse conditions in the field. Carneiro (1995) proposed the interval of 5.5 to 8 . I for this ratio as a standard for the classification of quality seedlings. Thus, as demonstrated in Table 4, these treatments are classified within the proposed standard.

Table 4 shows that the use of goat manure in the substrate provided the highest values (2.03) for the DMAP/DRM ratio, while the other treatments promoted the lowest values for this variable. This ratio indicates the stability between the growth of the aerial part and a seedling root, and the former structure should not be

TABLE 4 Dry mass of the aerial part (DMAP), ratio of length of the aerial part to the root collar (LAP/RC) and ratio of fresh mass of the aerial part and dry mass of the aerial part (FMAP/DMAP) of Copaiba seedlings produced in regional organic residues.

\begin{tabular}{cccc}
\hline \multirow{2}{*}{ Treatment $^{(1)}$} & DMAP & LAP/RC & FMAP/DMAP \\
\cline { 2 - 4 } NRH & $\mathrm{g}$ & - & - \\
GM & $0.37 \mathrm{~b}$ & $5.03 \mathrm{~b}$ & $0.82 \mathrm{~b}$ \\
CRH & $0.48 \mathrm{~b}$ & $5.39 \mathrm{~b}$ & $2.03 \mathrm{a}$ \\
CR & $0.43 \mathrm{~b}$ & $6.17 \mathrm{ab}$ & $0.87 \mathrm{~b}$ \\
Test & $0.74 \mathrm{a}$ & $7.17 \mathrm{a}$ & $1.27 \mathrm{~b}$ \\
C.V. $(\%)$ & $0.5 \mathrm{Ib}$ & $7.10 \mathrm{a}$ & $1.12 \mathrm{~b}$ \\
\hline
\end{tabular}

'NRH - in natura rice husk; GM - goat manure; CRH - carbonized rice husks; CR - carnauba residue; Test - soil without residue, Means followed by the same letter are not different from each other according to Tukey's test at $5 \%$; C.V.\% = coefficient of variation. 
much larger than the second, in order to avoid possible problems concerning the absorption of water. This is a major characteristic when the seedlings are taken to the field (Caldeira, 2008).

When the residues using bokashi are evaluated, significant effects are seen in the morphological and physiological variables of the plants (Table 5). For the variable root length, the smallest result $(10.48 \mathrm{~cm})$ was observed in the treatment with goat manure, and there was no significant difference between the other treatments. Also, in dry root mass, the lowest value was observed in the substrate with goat manure and in natura rice husk (DRM $-0.3 \mathrm{I}$ and $0.38 \mathrm{~g}$, respectively). When bokashi was not used, the lowest values for DRM were observed in the GM treatment and for FRM there was no significant difference among the treatments (Table 5).

According to Taiz and Zeiger (2017) and Wang et al. (20I8), the availability of mineral elements such as P, $\mathrm{K}, \mathrm{Ca}, \mathrm{Mg}$ and $\mathrm{N}$ has an effect on the initial growth of the plants and can reduce the need for a greater expansion of the root system related to the high availability of these macronutrients. This corroborates the values observed in the treatment with goat manure in which these elements are present, except for K (Table I).

Among the treatments used, the highest values of chlorolophyll $\mathrm{a}$ and $\mathrm{b}$ were observed in the treatments with carnaúba residue and goat manure (Table 5). This result was already expected, since the highest concentrations of nitrogen and the smallest $\mathrm{C}: \mathrm{N}$ ratio are in these organic residues (Table I), $\mathrm{N}$ being one of the

TABLE 5 Root length (RL), fresh root mass (FRM), dry root mass (DRM), quantity of chlorophyll a (QCA), quantity of chlorophyll b (QCB), and Dickson quality index (DQI) of Copaiba seedlings produced with regional organic residues and bokashi fermented compost.

\begin{tabular}{|c|c|c|c|c|c|c|}
\hline nent $^{(1)}$ & $\mathrm{RL}$ & FRM & DRM & QCA & QCB & DQI \\
\hline & $\mathrm{cm}$ & - & & - & - & - \\
\hline & \multicolumn{6}{|c|}{ With bokashi } \\
\hline $\mathrm{NRH}$ & $\mathrm{aA}$ & $70 \mathrm{bB}$ & $0.38 \mathrm{bB}$ & $23.85 \mathrm{bA}$ & $4.12 \mathrm{bA}$ & Idd \\
\hline G & bA & $0.62 \mathrm{bA}$ & $0.3 \mathrm{IbA}$ & $31.10 \mathrm{aA}$ & $\mathrm{aA}$ & $\mathrm{BaA}$ \\
\hline $\mathrm{CRH}$ & & $a b A$ & $0.49 \mathrm{abA}$ & & & \\
\hline CR & $63 \mathrm{aA}$ & $1.49 \mathrm{aA}$ & $0.7 \mathrm{IaA}$ & $32.57 \mathrm{aB}$ & 8.37aB & $0.17 \mathrm{aA}$ \\
\hline \multirow[t]{2}{*}{ Test } & $3 \mathrm{abA}$ & $0.97 \mathrm{abA}$ & $0.47 \mathrm{abA}$ & $21.03 \mathrm{bA}$ & $85 \mathrm{bA}$ & $0.12 \mathrm{aA}$ \\
\hline & \multicolumn{6}{|c|}{ Without bokashi } \\
\hline $\mathrm{NRH}$ & $13 \mathrm{aA}$ & $\mathrm{IaA}$ & $0.59 \mathrm{aA}$ & $27.52 \mathrm{bcA}$ & $5.75 \mathrm{bcA}$ & $0.18 \mathrm{a}$ \\
\hline GM & $6.78 \mathrm{bB}$ & $0.40 \mathrm{aA}$ & $0.19 \mathrm{bA}$ & 32.55abA & $8.00 \mathrm{bA}$ & $0.07 \mathrm{bB}$ \\
\hline $\mathrm{CRH}$ & 13.75abA & $0.97 \mathrm{aA}$ & $0.53 \mathrm{aA}$ & $21.07 \mathrm{cdA}$ & $4.00 \mathrm{cA}$ & $0.14 \mathrm{abA}$ \\
\hline CR & $13.48 \mathrm{aA}$ & $1.02 \mathrm{aB}$ & $0.52 \mathrm{aB}$ & $39.05 \mathrm{aA}$ & $12.60 \mathrm{aA}$ & $0.15 \mathrm{a} A$ \\
\hline Test & $12.98 \mathrm{abA}$ & $0.94 \mathrm{aB}$ & $0.27 \mathrm{abA}$ & $17.30 \mathrm{dA}$ & $2.83 c B$ & $0.12 \mathrm{abA}$ \\
\hline C.V. (\%) & 11.38 & 30.93 & 26.90 & 12.33 & 23.93 & 25.97 \\
\hline
\end{tabular}

'NRH - in natura rice husk; GM - goat manure; CRH - carbonized rice husks; CR - carnauba residue; Test - soil without residue; Lower case letters compare substrates within the bokashi and upper-case letters with and without bokashi in each substrate. Lower case letters compare residues within bokashi and upper-case letters the bokashi within each residue; Means followed by the same letter are not different from each other according to Tukey's test at $5 \%$; C.V.\% = coefficient of variation. sought-after elements in the plants, with direct action on the chlorophyll synthesis (Taiz and Zeiger, 2017).

There was no significant difference for the Dickson Quality Index (DQI) among the substrates evaluated with the application of bokashi. In general, the DQI presented low values in all treatments (Table 5). This may be related to DRM which also presented low values, thus implying a lower total dry mass of the seedlings. However, in this case the DQI may not directly reflect the quality of the Copaiba seedlings, since the smaller root mass may be due to the effect of the organic residues used, which present significant concentrations of macronutrients reducing the need for a greater expansion of the roots. Thus, it is very important to perform other associated analyses, such as physiological and nutritional ones to evaluate the quality of forest seedlings, besides the morphological parameters.

In the deployments of bokashi in each residue, it was observed that when it was applied there was an increase in the values of the RC and DQI with GM in FRM and DRM and QCB in the control. On the other hand, when no bokashi was used the highest values were observed in the variables FRM, DRM and DQI in treatment with $\mathrm{NRH}$ and in the $\mathrm{CR}$ treatment in variables QCA and QCB (Table 5).

The application of bokashi in the substrate with GM may have caused the immobilization of $\mathrm{N}$ and, thus, diminished the contents of this element in the substrate. According to Hafle et al. (2009) and Boechat et al. (2013) very high doses of this compost can acidify the soil and even immobilize nitrogen during decomposition, as well as residues based on NRH and $\mathrm{CRH}$ which present high C:N ratios of 259.7:I and 78.7:I, respectively (Table I) that would account for the smaller quantity of chlorophyll.

There was no significant difference for the LAP variable with and without bokashi. However, JaramilloLópez et al. (2015) observed after a year of planting in a reforestation area that there was a high rate of survival and greater growth of Pinus seedlings submitted to applications of bokashi. In the presence of bokashi the Copaiba seedling produced a greater number of folioles compared to when it was not applied (Table 6). Similar results were found by Hafle et al. (2009), who verified that the addition of the bokashi compost promoted an increased LAP and FOL. The number of folioles is related to the production of phytosynthates in the photosynthesis process. In this sense, Reis et al. (20/3) say that the greater the number of leaves and folioles, the greater will be the photosynthetic conversion and, consequently, the more growth of the seedlings.

Table 7 shows that for the P content in the aerial part of the seedlings there was no significant difference 
TABLE 6 Length of the aerial part (LAP) and number of folioles (FOL) of Copaiba seedlings produced with and without applying fermented bokashi compost.

\begin{tabular}{ccc}
\hline Treatment & LAP & FOL \\
\cline { 2 - 3 } & $\mathrm{cm}$ & unit \\
\hline With bokashi & $16.50 \mathrm{a}$ & $11.65 \mathrm{a}$ \\
Without bokashi & $15.38 \mathrm{a}$ & $9.85 \mathrm{~b}$ \\
C.V. (\%) & 11.28 & 25.64 \\
\hline
\end{tabular}

Means followed by the same letter are not different from each other according to Tukey's test at $5 \%$; C.V.\% = coefficient of variation.

between the residues when bokashi was applied. The values varied between $0.07 \mathrm{~g} \cdot \mathrm{kg}^{-1}$ (control) and $0.36 \mathrm{~g} \mathrm{~kg}^{-1}$ in dry mass (goat manure). However, without applying bokashi the highest phosphorus content in the aerial part of the seedlings was observed in GM treatment $(9.38 \mathrm{~g}$ $\mathrm{kg}^{-1}$ in dry weight) and the lowest value $\left(0.16 \mathrm{~g} \mathrm{~kg}^{-1}\right.$ in dry weight) in the control (Table 7). This result was already expected, since goat manure has a five times greater $\mathrm{P}$ content in the compost than carnauba residue (Table I).

TABLE 7 Macronutrient contents in the aerial part of the Copaiba seedlings produced with regional organic residues and fermented bokashi compost.

\begin{tabular}{|c|c|c|c|c|}
\hline \multirow{2}{*}{ Treatment $^{(\mathrm{l})}$} & $\mathrm{Pl}$ & $\mathrm{K}$ & $\mathrm{Ca}$ & $\mathrm{Mg}$ \\
\hline & \multicolumn{2}{|c|}{$\mathrm{g} \cdot \mathrm{kg}^{-1}$} & \multicolumn{2}{|c|}{$-\mathrm{mg} \cdot \mathrm{kg}^{-1}$} \\
\hline & \multicolumn{4}{|c|}{ With bokash } \\
\hline $\mathrm{NRH}$ & $0.16 \mathrm{aB}$ & $8.30 \mathrm{bA}$ & $5.53 \mathrm{bA}$ & $1.95 \mathrm{~cd} A$ \\
\hline GM & $0.36 \mathrm{aB}$ & $12.37 \mathrm{aA}$ & $15.40 \mathrm{aA}$ & $7.63 \mathrm{aA}$ \\
\hline $\mathrm{CRH}$ & $0.17 \mathrm{aB}$ & $9.09 \mathrm{bA}$ & $9.6 \mathrm{lbA}$ & $3.28 \mathrm{bcA}$ \\
\hline CR & $0.15 \mathrm{aB}$ & $7.75 \mathrm{bA}$ & $9.53 \mathrm{bA}$ & $4.49 \mathrm{bA}$ \\
\hline \multirow[t]{2}{*}{ Test } & $0.07 \mathrm{aB}$ & $3.72 \mathrm{cB}$ & $0.83 \mathrm{cB}$ & $0.67 \mathrm{~dB}$ \\
\hline & \multicolumn{4}{|c|}{ Without bokashi } \\
\hline $\mathrm{NRH}$ & $4.02 \mathrm{bA}$ & $7.26 \mathrm{aA}$ & $7.31 \mathrm{bA}$ & $2.59 \mathrm{cA}$ \\
\hline GM & $9.38 \mathrm{aA}$ & $7.67 \mathrm{aB}$ & $16.79 \mathrm{aA}$ & $6.90 \mathrm{aA}$ \\
\hline $\mathrm{CRH}$ & $4.48 \mathrm{bA}$ & $8.92 \mathrm{aA}$ & $4.46 \mathrm{bB}$ & $2.22 \mathrm{cB}$ \\
\hline $\mathrm{CR}$ & $4.98 \mathrm{bA}$ & $6.55 \mathrm{aA}$ & $7.87 \mathrm{bA}$ & $4.57 \mathrm{bA}$ \\
\hline Test & $0.16 \mathrm{cA}$ & $8.35 \mathrm{aA}$ & $5.49 \mathrm{bA}$ & $2.68 \mathrm{cA}$ \\
\hline C.V. (\%) & 30.82 & I6.1 & 27.24 & 17.75 \\
\hline
\end{tabular}

' Macronutrient content in kg of dry mass; NRH - in natura rice husk; GM - goat manure; CRH - carbonized rice husk; CR -carnauba residue; Test - soil without residue; Lower case letters compare residues within bokashi and upper-case letters the bokashi within each residue; Means followed by the same letter are not different from each other according to Tukey's test at $5 \%$; C.V.\% = coefficient of variation.

Comparing the contents of $\mathrm{P}$ in the treatments with and without bokashi, an increment was observed in the aerial part of the seedlings in the absence of bokashi (Table 7). These results can be explained by the fact that probably part of the $\mathrm{P}$ made available by the residues could be immobilized in the microorganisms stimulated by the application of bokashi, and is made available according to the need of the plants. This hypothesis is explained, because $P$ is absorbed in smaller quantities among the macronutrients and interferes directly in processes such as photosynthesis, respiration, storage and transfer of energy, cell division, cell growth, and others (Steccanella et al., 2015; Taiz and Zeiger, 2017), in other words $\mathrm{P}$ deficiency would mean a reduction of the variables length, dry mass of roots, chlorophyll $a$ and $b$, length of the aerial part and number of folioles (Tables 5 and 6), which was not observed.
Among the residues with the application of bokashi, the highest contents of $\mathrm{K}, \mathrm{Ca}$ and $\mathrm{Mg}$ in the aerial part were observed with GM (I2.37 g. $\mathrm{kg}^{-1}$; 15.40 $\mathrm{mg} \mathrm{kg}^{-1}$ and $7.63 \mathrm{mg} \cdot \mathrm{kg}^{-1}$ dry weight, respectively) and the lowest values were observed in the control $\left(3.72 \mathrm{~g} \mathrm{~kg}^{-1}\right.$; $0.83 \mathrm{mg} \cdot \mathrm{kg}^{-1}$ and $0.67 \mathrm{mg} \cdot \mathrm{kg}^{-1}$ dry weight, respectively). The increased availability of $K$ is related to applying bokashi, considering that the goat manure is deficient in $\mathrm{K}$ available to the plants. However, the composition of GM presents the highest quantities of $\mathrm{Ca}$ and $\mathrm{Mg}$ (Table I). Thus, in the treatments without bokashi, the aerial part of the Copaiba seedlings produced with GM presented the highest contents of $\mathrm{Ca}$ and $\mathrm{Mg}$ ( 16.79 $\mathrm{mg} \cdot \mathrm{kg}^{-1}$ and $6.90 \mathrm{mg} \cdot \mathrm{kg}^{-1}$ dry weight, respectively). There was no significant different in the content of $\mathrm{K}$ among the substrates tested without applying bokashi (Table 7).

The $\mathrm{K}, \mathrm{Ca}$ and $\mathrm{Mg}$ contents, with and without applying bokashi, were different only in the GM, CAC and control treatments, and in the GM with bokashi the $\mathrm{K}$ content was highest ( $12.37 \mathrm{~g} \cdot \mathrm{kg}^{-1}$ dry weight) and in CAC with bokashi the highest contents of $\mathrm{Ca}$ and $\mathrm{Mg}$ (9.6 $\mathrm{mg} \cdot \mathrm{kg}^{-1}$ and $3.28 \mathrm{mg} \cdot \mathrm{kg}^{-1}$ dry weight, , respectively), and in the control without the bokashi the highest values for $\mathrm{K}, \mathrm{Ca}$ and $\mathrm{Mg}\left(8.35 \mathrm{~g} \cdot \mathrm{kg}^{-1} ; 0.83\right.$ and $0.67 \mathrm{mg} \cdot \mathrm{kg}^{-1}$ dry weight, respectively). This result indicates that in the case of the control the presence of the microorganisms associated with a soil with low $\mathrm{K}, \mathrm{Ca}$ and $\mathrm{Mg}$ content diminished the availability of the nutrients (Tables 2 and 7). However, Jaramillo-López et al. (20I5) observed increases in the nutrient contents in soil, mainly $\mathrm{Ca}$ and $\mathrm{Mg}$ in reforestation areas in which bokashi was applied.

The results of this study confirm the hypothesis that the use of substrates should be taken into account in planning seedling production, especially in the region where the study was performed. Thus, it is valid to emphasize the importance of studies with the production of seedlings from other species of the Caatinga and Cerrado biomes for the restoration of degraded areas, reforestation and phytoremediation, ensuring a greater chance of success by using quality seedlings. The use of these regional organic residues to produce seedlings is at the same time an economically feasible and environmentally sustainable practice.

\section{CONCLUSION}

The use of Fertbokashi premium ${ }^{\circledR}$ associated with organic residues achieves the best results for most morphophysiological and nutritional variables of the copaiba seedlings, also stimulates maximum utilization and better response to phosphorus in plants tissues from substrate. The 
substrates formulated with carnauba residue or goat manure are the most appropriate for the nutrition and production of copaiba seedlings. The regional organic residues can be used as a substrate to produce copaiba seedlings with a high standard of quality and low cost.

\section{ACKNOWLEDGMENT}

The authors would like to thank National Council for Scientific and Technological Development (CNPq) and Federal University of Piauí (UFPI) for financial support and collaborating in this study and Korin Agropecuária Ltda for donating the bokashi product.

\section{REFERENCES}

AMARAL, F. H. C.; NÓBREGA, J. C. A.; NÓBREGA, R. S. A.; LUSTOSA FILHO, J. F.; AMORIM, S. P. N. Growth of Leucaena leucocephala (Lam.) de Wit favored by organic waste in the Brazilian semiarid region. Revista Brasileira de Engenharia Agrícola e Ambiental, v. 20, n. 7, p. 612 617,2016

ARAÚJO, E. F., ARAUCO, A. M. D. S., DIAS, B. A. S., SILVA, G. C. D., NÓBREGA, R. S. A. Substrates of Mauritia flexuosa and wastewater from pig farming on growth and quality in seedlings of Acacia mangium. Revista Ciência Agronômica, v. 49, n. 2, p. 298-306, 2018.

ARAÚJO, E. F.; ARAUCO, A. M. S.; LACERDA, J. J. J.; RATKE, R. F; MEDEIROS, J. C. Crescimento e balanço nutricional de mudas de Enterrolobium contortsiliquum com aplicação de substratos orgânicos e água residuária. Pesquisa Florestal Brasileira, v. 36, n. 86, p. 169-177, 2016.

ASENSIO, V.; FLÓRIDO, F. G.; RUIZ, F; PERLATTI, F; OTERO, $X$. L.; FERREIRA, T. O. Screening of native tropical trees for phytoremediation in copper-polluted soils. International Journal of Phytoremediation, v. 20, p. I456-|463, 2018.

BOECHAT, C. L.; ARAUCO, A. M. S.; RIBEIRO, M. O.; BRITO, A. C. C.; SOUZA, A. A.; SANTOS, J. A. G. Soil chemical attributes and initial growth of corn crop by adding domestic and industrial sewage sludge. Bioscience Journal, v. 33, p. 886-896, 2017

BOECHAT, C. L.; SANTOS, J. A. G.; ACCIOLY, M. A. Net mineralization nitrogen and soil chemical changes with application of organic wastes with 'Fermented Bokashi Compost. Acta Scientiarum. Agronomy, v. 35, n. 2, p. 257-264, 2013

BOECHAT, C. L.; SANTOS, J. A. G.; ACCIOLY, A. M. A.; BOMFIM, M. R.; SANTOS, A. C. Industrial and urban organic wastes increase soil microbial activity and biomass. Revista Brasileira de Ciência do Solo, v. 36, p. 1629. 1636, 2012.

CALDEIRA, M. V. W.; ROSA, G. N.; FENILLI, T. A. B.; HARBS, R. M. P.; Composto orgânico na produção de mudas de aroeira- vermelha. Revista Scientia Agraria, v. 9, n. I, p. 27-33, 2008.
CARNEIRO, J. G. A. Produção e controle de qualidade de mudas florestais. Curitiba: UFPR/FUPEF, 1995.

DANILEVICZ, M. F; MOHARANA, K. C.; VENANCIO, T. M.; FRANCO, L. O.; CARDOSO, S. R. S.; CARDOSO, M.; THIEBAUT, F.; HEMERLY, A. S.; PROSDOCIMI, F; FERREIRA, P. C. G. Copaifera langsdorffii novel putative long non-coding RNAs: interspecies conservation analysis in adaptive response to different biomes. Non-Coding RNA, v. 4 , p. $|-2|, 2018$

DAMASCENO, A. S. S.; BOECHAT, C. L.; MORAIS, J.; GONÇALVES, B. P. S.; ARAUCO, A. M. S. Soil classes and regional organic residues affect nutrition, morphophysiology and quality of copaiba seedlings. Cerne, v. 25, n. 2, p. I31-139, 2019.

FERREIRA, D. F. Sisvar: a computer statistical analysis system. Ciência e Agrotecnologia, v. 35, p. 1039- 1042, 201 I.

GUEDES, M. G. M.; SILVA JUNIOR, M. L.; SILVA G. R.; SILVA, A.L.P.; LIMA JUNIOR, J. A. Produção de matéria seca em mudas de copaíba cultivadas em Latossolo Amarelo, textura média, sob omissão de nutrientes. Revista Enciclopédia Biosfera, v. 7, n. 12, p. I-14, 2011 .

GOMES, J. M.; COUTO, L.; LEITE, H. G.; XAVIER, A.; GARCIA, S. L. R. Crescimento de mudas de Eucalyptus grandis em diferentes tamanhos de tubetes e fertilização N-P-K. Revista Árvore, v. 27, p. I I3-127, 2003.

GONÇALVES, J. L. M.; POGGIANI, F. Produção de mudas de espécies nativas: substrato, nutrição, sombreamento e fertilização. In: GONÇALVES, J. L. M.; BENEDETTI, V. (Eds.) Nutrição e fertilização florestal. Piracicaba: IPEF, 2000. p. 80-102.

HAFLE, O. M.; SANTOS, V. A.; RAMOS, J. D.; CRUZ, M. C. M.; MELO, P. C. Produção de mudas de mamoeiro utilizando bokashi e lithothamnium. Revista Brasileira de Fruticultura, v. 3I, n. I, p. 245-25I, 2009.

IBÁ - Indústria Brasileira de Árvores. Relatório IBÁ 2017 ano base 2016. Brasília: 2017. 80 p. Disponível em: < https://www.iba.org/datafiles/publicacoes/pdf/ibarelatorioanual2017.pdf >. Acesso em: 22 ago. 2019.

KÖPPEN, W. Climatologia: con un estudio de los climas de la tierra. Fondo de Cultura Econômica. México. 1948, 479p.

JARAMILLO-LÓPEZ, P. F; RAMIREZ, M. I.; PÉREZ-SALICRUP, D. R. Impacts of Bokashi on survival and growth rates of Pinus pseudostrobus in community reforestation projects. Journal of Environmental Management, v. I50, p. 48-56, 2015.

JEROMINI, T. S.; FACHINELLI, R.; SILVA, G. Z.; PEREIRA, S. T. S.; SCALON, S. P. Q. Emergência de plântulas e crescimento inicial de copaíba sob diferentes substratos. Pesquisa Florestal Brasileira, v. 37, n. 90, p. 219-223, 2017.

MAYER, J.; SCHEID, S.; WIDMER, F; FLIEBACH, A; OBERHOLZER, H. R. How effective are 'Effective microorganisms (EM)'? Results from a field study in temperate climate. Applied Soil Ecology, v. 46, p. 230239, 2010. 
MOREIRA, M. M., NÓBREGA, R. S. A.; SANTOS, R. P. dos. SILVA, C. C.; NOBREGA, J. C. A. Cultivation of Caesalpinia pulcherrima L. Sw. in regional substrates. Revista Árvore, v. 42, n. 2, e420212, 2018.

NÓBREGA, R. S. A.; PAULA, A. M.; BOAS, R. C. V.; NÓBREGA, J. C. A.; MOREIRA, F. A. S. Parâmetros morfológicos de mudas de Sesbania virgata (Caz.) Pers e de Anadenanthera peregrina (L.) cultivadas em substrato fertilizado com composto de lixo urbano. Revista Árvore, v. 32, n. 3, p. 597-607, 2008.

NÓBREGA, R. S. A; BOAS, R.C.V.; NOBREGA, J. C. A.; PAULA, A. M.; MOREIRA, F. M. S. Utilização de biossólido no crescimento inicial de mudas de aroeira (Schinus terebynthifolius Raddi). Revista Árvore, v. 3I, n. 2, p. 239-246, 2007.

OLIVEIRA, E. C. P.; LAMEIRA, O. A.; ZOGHBI, M. G. B. Identificação da época de coleta do óleo-resina de copaíba (Copaifera spp.) no município de Moju-PA. Revista Brasileira de Plantas Medicinais, v. 8, n. 3, p. 14-23, 2006.

PAIVA SOBRINHO, S. P.; LUZ, P. B.; SILVEIRA, T. L. S.; RAMOS, D. T.; NEVES, L. G.; BARELLI, M.A.A.; Substratos na produção de mudas de três espécies arbóreas do cerrado. Revista Brasileira Ciências Agrárias, v. 5, n. 2, p. 238243, 2010.

REIS, S. M.; MARIMOM JUNIOR, B. H.; MORANDI, P. S.; SANTOS, C. O.; OLIVEIRA, B.; MARIMOM B. S.; Desenvolvimento inicial e qualidade de mudas de Copaifera langsdorfii Desf. Sob diferentes níveis de sombreamento. Revista Ciência Florestal, v. 26, n. I, p. II-20, 2016.

ROCHA, I. T. M.; SILVA, A. V.; SOUZA, R. F.; FERREIRA, J. T. P. Uso de resíduos como fonte de nutrientes na agricultura. Revista Verde, v. 8, p. 47 - 52, 2013.
SOIL SURVEY STAFF. Keys to Soil Taxonomy. 12th ed. Washington: USDA - Natural Resources Conservation Service, 2014.

STECCANELLA, V.; HANSSON, M.; JENSEN, P. E. Linking chlorophyll biosynthesis to a dynamic plastoquinone pool. Plant Physiology and Biochemistry, v. 97, p. 207-2 I6, 2015.

SHIN, K., VAN DIEPEN, G., BLOK, W.; VAN BRUGGEN, A. H. C. Variability of Effective Micro-organisms (EM) in bokashi and soil and effects on soil-borne plant pathogens. Crop Protection, v. 99, p. 168-176, 2017.

TAIZ, L.; ZEIGER, E. Fisiologia e Desenvolvimento Vegetal. $6^{\mathrm{a}}$ ed. Porto Alegre: Artmed Editora. 2017. 858p.

TEDESCO, M.J.; GIANELLO, C.; BISSANI, C.A.; BOHNEN, H.; VOLKWEISS, S.J. Análise de solo, plantas e outros materiais. 2.ed. Porto Alegre, Universidade Federal do Rio Grande do Sul, 1995. 147p. (Boletim Técnico, 5).

TEIXEIRA, P. C.; DONAGEMMA, G. K.; FONTANA, A.; TEIXEIRA, W. G. Manual de métodos de análise de solos. $3^{\mathrm{a}}$ ed. Rio de Janeiro: Embrapa Solos. 2017. 573p.

TSUKAMOTO FILHO, A. A.; CARVALHO, J. L. O.; COSTA, R. B.; DALMOLIN, A. C. BRONDANI, G. E. Regime de regas e cobertura de substrato afetam o crescimento inicial de mudas de Myracrodruon urundeuva. Floresta e Ambiente, v. 20 , p. $521-529,2013$.

WANG, P.; YANG, Y.; MOU, P.; ZHAO, Q.; LI, Y. Local root growth and death are mediated by contrasts in nutrient availability and root quantity between soil patches. Proceedings of the Royal Society B, v. 285, 20180699, 2018. 